\title{
Does Attestation of the Effectiveness of Internal Control over Financial Reporting Discourage Earnings Management? Evidence from China
}

\author{
Li Dang $^{1} \&$ Qiaoling Fang ${ }^{2}$ \\ ${ }^{1}$ Orfalea College of Business, California Polytechnic State University, San Luis Obispo, USA \\ ${ }^{2}$ College of Management, Ocean University of China, Qingdao, China \\ Correspondence: Li Dang, Orfalea College of Business, California Polytechnic State University, 1 Grand Avenue, San \\ Luis Obispo. CA 93407, USA
}

Received: July 26, 2018

Accepted: August 17, 2018

Online Published: August 24, 2018

doi:10.5430/afr.v7n4p1

URL: https://doi.org/10.5430/afr.v7n4p1

\begin{abstract}
To improve financial reporting quality, the Chinese government issued the Basic Standard for Enterprise Internal Control in 2008 and other related guidelines/regulations in the following years (hereafter China SOX). The scope of China SOX is broader but similar to Section 404 of the Sarbanes-Oxley Act (SOX) in the U.S. Formal adoptions of China SOX requires management and external auditor's report on the effectiveness of internal control over financial reporting (ICFR). A company's ICFR, if effective, should provide reasonable assurance that the company's financial statements are reliable and prepared in accordance with the applicable accounting standards. The purpose of this study is to investigate whether China external auditor attestation of ICFR discourage earnings management, an indicator of financial reporting quality. Following prior research, we use performance matched discretionary accruals as the proxy for earnings management. We empirically analyze a sample of Chinese public firms for the period 2011-2013 and find that: (1) Chinese firms that disclose audited ICFR reports exhibit lower earnings management than firms that do not; (2) Chinese firms that are mandated to disclose audited ICFR reports exhibit lower earnings management than firms that voluntarily disclose audited ICFR reports. Our empirical results seem to suggest that attestation of the effectiveness of ICFR discourages earnings management and therefore improve financial reporting quality.
\end{abstract}

Keywords: ICFR, financial reporting quality, earnings management, discretionary accruals, China SOX

\section{Introduction}

To improve financial reporting quality, the Chinese government began developing regulatory standards for internal controls about a decade ago. From 2008 to 2012, China issued three regulatory documents (Note 1) regarding enterprise internal controls. The scope of these regulations is broader but similar to Section 404 of the Sarbanes-Oxley Act (SOX) in the U.S. (Note 2) Therefore, we refer to these internal control regulations as China SOX. China SOX places an emphasis on internal control over financial reporting (ICFR) with a goal to improve transparency of financial reporting. Firms that adopt China SOX are required to provide a self-assessment report on the effectiveness of their internal control and an external auditor's report on the effectiveness of ICFR.

"Internal controls" refer to those procedures within a company that are designed to reasonably ensure compliance with the company's policies. The Basic Standards include five elements of internal controls, which is similar to the COSO framework. (Note 3) According to the framework developed by the Committee on Sponsoring Organizations (COSO), there are three types of internal controls: (1) those that affect a company's operations; (2) those that affect a company's compliance with laws and regulations, and (3) those that affect a company's financial reporting (COSO, 1992). ICFR refers to the third type of internal controls. The Public Accounting Oversight Board defines ICFR as the following:

Internal control over financial reporting is a process designed by, or under the supervision of, the company's principal executive and principal financial officers, or persons performing similar functions, and effected by the company's board of directors, management and other personnel, to provide reasonable assurance regarding the reliability of financial reporting and 
the preparation of financial statements for external purposes in accordance with GAAP and includes those policies and procedures that --

(1) Pertain to the maintenance of records that, in reasonable detail, accurately and fairly reflect the transactions and dispositions of the assets of the company;

(2) Provide reasonable assurance that transactions are recorded as necessary to permit preparation of financial statements in accordance with generally accepted accounting principles, and that receipts and expenditures of the company are being made only in accordance with authorizations of management and directors of the company; and

(3) Provide reasonable assurance regarding prevention or timely detection of unauthorized acquisition, use, or disposition of the company's assets that could have a material effect on the financial statements

To fulfill its financial reporting responsibilities, management needs to rely on the design and effectiveness of the processes and safeguards it has put in place over financial reporting. A company's ICFR, if effective, should provide reasonable assurance that the company's financial statements are reliable and prepared in accordance with the applicable accounting standards. Attestation of ICFR provides additional monitoring from an independent external third party. It should motivate management to maintain/improve the effectiveness of ICFR. It is reasonable to believe that attestation of ICFR helps ensure financial reporting quality.

Additionally, the ICFR audit, if integrated with the financial statement audit, may help improve the effectiveness of the financial statement audit. It is critical for the external auditor to understand the client company's ICFR. Assessing the effectiveness of the ICFR is an important part of audit planning. An audit of a client company's ICFR helps the external auditor obtain sufficient appropriate audit evidence to support the auditor's control risk assessments for purposes of the audit of financial statements. Ultimately, the ICFR audit might help improve financial reporting quality through improved audit quality.

Prior studies have provided empirical evidence that effective ICFR enhances financial reporting quality (e.g., Altamuro \& Beatty, 2009; Brown et al., 2014; Chan et al. 2008; Dowdell et al., 2014; Foster \& Shastri, 2013; He \& Thorton, 2013; Krishnan \& Yu, 2012; Nagy 2010; Singer \& You, 2011). Alternatively, weak ICFR is associated with less reliable accounting information (Ashbaugh-Skaife et al., 2008; Doyle et al., 2007; Feng et al., 2015; Lu et al., 2011) because ineffective ICFR may provide more room for management discretion over accounting estimates and methods (Hogan \& Wilkins, 2008). After the Basic Standard was issued in 2008, many Chinese public firms started to voluntarily report on ICFR (Note 4). Chinese firms that are cross listed in both domestic and foreign stock markets were required to adopt China SOX and include an auditor's report on ICFR in their 2011 fiscal year annual reports. Prior to fiscal year 2011, all adoptions were voluntary. Because China SOX requires external attestation of ICFR and aims to improve financial reporting, it is interesting and important to investigate whether attestation of ICFR has improved financial reporting quality through discouraging earnings management. In this study, we primarily use discretionary accruals as a proxy for earnings management.

By analyzing a sample of Chinese public firms during the period of 2011-2013, we find that firms that disclose audited ICFR reports exhibit lower absolute discretionary accruals than firms that do not. This result is robust to an alternative measure for earnings management, the excess non-operating income. Furthermore, compare to firms that voluntarily disclose audited ICFR reports, mandatory firms exhibit even lower absolute discretionary accruals. Because firms that are mandated to adopt China SOX might be fundamentally different from other firms, we compare firms that voluntarily disclose audited ICFR reports with non-disclosing firms. Voluntary firms show lower absolute discretionary accruals than non-disclosing firms. Additionally, we performed a pre and post comparison within a list of firms that started disclosing audited ICFR reports either in 2012 or 2013. In other words, these firms did not adopt China SOX in 2011. We find that the absolute discretionary accruals significantly reduced in the first year of formal ICFR disclosure. Overall, the findings of this study suggest that attestation of ICFR helps reduce earnings management and therefore improve financial reporting quality.

Our study makes a few important contributions. Prior studies that examine the association between ICFR and earnings/financial reporting quality are mostly conducted in the U.S. context. It is important to extend the literature in the Chinese context because China has a very different institutional background. For example, more than half of Chinese public firms are in the manufacturing sector. There is also a high percentage of state ownership in the public firms. In fact, the top 12 largest Chinese firms are all state-owned (Fortune, 2015). Ji et al. (2017) investigate the relationship between voluntary disclosure of internal control weaknesses (ICWs) and earnings quality among 
Chinese public firms. They find a positive relationship between the number of ICW disclosed and the level of absolute discretionary accruals. Such a result suggests a positive relation between the effectiveness of ICFR and financial reporting quality. While Ji et al. explore voluntary disclosure of ICWs, we focus on audit assurance of ICFR and study both voluntary and mandatory disclosure of audited ICFR. As the world's second-largest economy, China plays an important role in the world's economy. Despite the size of its economy, China's stock markets are still immature and the internal control regulations (e.g., China SOX) are still in the process of being fully adopted. To this day, not all public firms are mandated to adopt China SOX. Does attestation of ICFR add more credibility to financial reporting? Should all Chinese firms be required to have their ICFR audited by an external auditor? Our study addresses these questions and examines the impact of attestation of ICFR on financial reporting quality. Therefore, the results of this study provide feedback to Chinese regulators.

This study adds more empirical evidence supporting the positive effect of attestation of ICFR on financial reporting quality. Specifically, we find that firms (both voluntary and mandatory firms) that disclose audited ICFR reports show lower absolute discretionary accruals (higher financial reporting quality) than firms that do not. Such a result seems to suggest that attestation of ICFR helps motivate management to maintain/improve ICFR effectiveness and therefore improve financial reporting quality. This finding is consistent with prior research that has documented a positive relationship between effectiveness of ICFR and financial reporting quality (Altamuro \& Beatty, 2009; Brown et al., 2014; Chan et al. 2008; Dowdell Jr. et al.2014; Foster \& Shastri, 2013; He \& Thorton, 2013; Krishnan \& Yu, 2012; Nagy 2010; Singer \& You, 2011).

Previous studies have provided positive feedback of voluntary adoptions of China SOX (e.g., Ji at al., 2015; Ji et al., 2016; Ji et al., 2017; Zhang \& Han, 2016). To our knowledge, little has been done on evaluating the outcomes of mandatary compliance. The result of this study shows that mandatory compliance firms show lower absolute discretionary accruals than voluntary compliance firms. This study seems to suggest that mandatory attestation of ICFR report elevates financial reporting quality in China.

The rest of paper is organized as follows: section 2 provides institutional background, reviews the literature and develops the hypothesis; section 3 describes data and research design; section 4 presents and discusses the results; and section 5 summarizes the paper.

\section{Background, Prior Research, and Hypothesis Development}

\subsection{Institutional Background}

To improve financial reporting quality, the Chinese government began developing its regulatory standards for internal control about a decade ago. In 2008, the five Chinese governmental departments (Note 5) jointly issued the Basic Standard for Enterprise Internal Control (hereafter the Basic Standard). According to the Basic Standard, adopting firms should disclose an annual self-assessment report on the effectiveness of internal control and may also hire an external auditor to attest to and report on the effectiveness of internal control. Originally, the Basic Standard was expected to be formally adopted in 2009. However, the adoption was delayed due to the need for more specific guidelines. To provide more adoption guidelines, the five Chinese governmental departments issued the Supporting Guidelines for Internal Control of Enterprises (hereafter Supporting Guidelines) in April 2010. It is important to note that the Supporting Guidelines heightened the adoption requirements and provided expected mandatory adoption timelines. According to the Supporting Guidelines, adopting firms are required to disclose an annual self-assessment report on the effectiveness of their internal control and should hire an external auditor to attest to and report on the effectiveness of their internal control over financial reporting. Moreover, firms that were cross listed in both domestic and oversea markets were mandated to adopt China SOX in fiscal year 2011.

In August 2012, the Chinese Ministry of Finance and the CSRC jointly issued the Notice on the Adoption of the Basic Standard of Enterprise Internal Control by Companies Listed on the Main Board under Different Categories and Groups as of 2012 (hereafter 2012 Notice). The 2012 Notice specified the mandatory adoption timelines of China SOX for firms listed on the main board markets. According to the 2012 Notice, (1) central and local state-owned enterprises (SOEs) should adopt China SOX in 2012; (2) non-SOEs with a total market value above five billion Renminbi as of December 31, 2011 and whose average net profit from 2009 to 2011 was above 30 million Renmingbi should adopt China SOX in 2013; (3) Other companies listed on the main board should adopt China SOX in 2014. The 2012 Notice encourages early voluntary adoptions. See Appendix A for China SOX adoption timelines.

\subsection{Prior Research and Hypothesis Development}

Prior research suggests that weak internal control allows more opportunities for earnings management and fraudulent financial reporting. Many studies that were done prior to Sarbanes-Oxley have provided indirect evidence on internal 
controls and financial reporting quality. For example, Kinney \& McDaniel (1989) examine a small sample of firms who corrected their previous reported quarterly earnings in the annual financial reports for the period of 1976 to 1985. If a firm has to correct its interim earnings due to accounting error(s), there should be a serious breach in the internal control system. Their result shows that the firms that made such corrections tend to be smaller than the industry mean (median), which suggests weak internal control. They also analyze the reasons for corrections and find that management may have overridden internal controls designed by themselves. Bell and Carcello (2000) developed a logistic regression model to predict fraudulent financial reporting by analyzing a sample of fraud and non-fraud audit engagements. "Weak internal control environment" is identified as one of the few strongest factors in predicting fraudulent financial reporting.

Because earnings management is more likely to occur under weak internal controls, many recent studies have directly examined the relationship between "internal control quality" and "discretionary accruals". Doyle et al. (2007) analyze ICFR using a sample of U.S. firms under Sections 302 and 404 of the Sarbanes-Oxley Act of 2002. They find a relationship between weaker internal control and lower accruals quality. They interpret this result as that management may intentionally use biased accruals to manage earnings under weak internal control environment. Chan et al. (2008) find that firms that report material internal control weaknesses exhibit more positive and absolute discretionary accruals than for other firms. Ashbaugh-Skaife et al. (2008) document that firms reporting internal control deficiencies have (1) lower quality accruals and (2) larger positive and negative accruals than controlled firms.

While the above studies focus on the consequences of weak internal controls, other studies indicate that strong internal control may limit earnings management and improve accounting quality. Jiambalvo (1996) suggests that "internal control" may limit within GAAP earnings manipulation and will limit non-GAAP earnings manipulation. Altamuro \& Beatty (2010) examine a sample of firms in the banking industry that are subject to the Federal Depository Insurance Improvement Act (FDICA) internal control provisions. They find that earnings management reduced in the post-FDICA period. Singer \& You (2011) examine the change in the magnitude of absolute abnormal accruals before and after the adoption of Sox 404. They find that adopting firms exhibit significantly lower absolute abnormal accruals in the post-SOX 404 period.

Additionally, many studies have provided empirical evidence on the benefits of attestation of ICFR. Foster \& Shastri (2013) find a positive impact of PCAOB regulation (standards related to ICFR) on audit quality and quality of revenue-accruals. Brown et al. (2014) investigate the impact of mandatory internal control and risk management (MICR) reform in Germany. One major component of this reform in Germany is internal control over financial reporting. They find that German firms experience an increase in accounting quality after the reform. Such increase in accounting quality is through effective internal control and risk management systems. While some studies focus on associations between attestation of ICFR and earnings/accounting quality measures based on accounting numbers, other studies explore the impact of ICFR attestation from an investors' perspective. For example, He \& Thorton (2013) find that firms exhibit investor-perceived earnings quality (IPEQ) increases after receiving their first unqualified SOX 404 audit reports signaling the remediation of previously reported ICFR weaknesses. Such a result suggest that SOX's 404 has a positive impact on enhancing investor confidence in reliability of financial reporting. In summary, prior studies have provided empirical evidence that there is a positive relationship between effectiveness of ICFR and earnings/accounting quality and that attestation of ICFR contribute to improving earnings/accounting quality.

Finally, a few studies have provided positive feedback of voluntary adoptions of China SOX and audit assurance of ICFR (e.g., Ji at al., 2015; Ji et al., 2016; Ji et al., 2017; Zhang \& Han, 2016). For instance, Zhang \& Han (2016) examine a list of Chinese firms that voluntarily adopted the Basic Standard in 2008. They find that separate audit assurance on ICFR improves overall audit quality. Ji et al. (2015) study voluntary China SOX adoptions in a different period of time (2010 and 2011) and find that audit assurance on internal controls mitigate the negative relationship between earnings response coefficients (ERC) and internal control weaknesses (ICWs). In a later study using the same sample, Ji et al. (2016) find that there is a negative relationship between accounting conservatism and ICWs and that additional assurance of internal control reports can mitigate the effect of ICWs on accounting conservatism. However, these studies have not directly tested the impact of attestation of ICFR on financial reporting quality in China. 
Based on prior research, we expect that China SOX compliance firms that have disclosed audited ICFR have a lower level of discretionary accruals compared with non-compliance firms. The hypothesis is stated in the following:

\section{H: Chinese firms that disclose audited ICFR reports exhibit lower earnings management than Chinese firms that do not.}

Mandatory adoptions of China SOX began in 2011. According to China SOX, firms that are cross listed on both the domestic and foreign stock markets are mandated to disclose audited ICFR starting from their 2011 annual report. Central and State SOEs are mandated to adopt China SOX in 2012. However, to this day, China SOX has still not been fully adopted by all Chinese public firms. Such an institutional background provides an opportunity to compare mandatory and voluntary attestation of ICFR and their possible different impacts on financial reporting quality. On the one hand, mandatory firms are subject to more scrutiny regarding their internal control effectiveness because their ICFR audit reports are to be reviewed by supervising agencies. It is reasonable to believe mandatory firms are more motivated to improve/maintain the effectiveness of their ICFR than voluntary firms. On the other hand, the management of firms that voluntarily adopt China SOX might have a strong belief in effective internal controls and therefore have created a good control environment. Therefore, these voluntary firms already have strong ICFR. For example, Hermanson (2000) finds that these users agree that voluntary internal control report would improve financial reporting quality, but they do not hold the same perception for mandatory internal control report. In other words, mandatory compliance might not add more additional value compared to voluntary compliance. With the two completing theories, instead of propose a hypothesis, we aim to answer the following research question.

RQ: Do Chinese firms that mandatorily disclose audited ICFR reports exhibit a different level of earnings management compared to firms that voluntary disclosing firms?

\section{Data and Research Design}

\subsection{Sample Selection}

Since mandatory adoptions of China SOX began in fiscal year 2011, our sampled period starts from 2011. Specifically, we selected our sample from firms whose A shares were traded in either the Shanghai Stock Exchange (SHSE) or the Shenzhen Stock Exchange (SZSE) from year 2011 to 2013. Data regarding ICFR audit reports were hand collected from public firms' annual reports. Other data were obtained from China Stock Market \& Accounting Research (CSMAR) database. We started with a total of 7,647 firm-year observations using CSMAR. Then we removed firms in the banking, financial service, and real estate industries (519 observations) and observations with missing data (863 observations). The final sample consists of 6,264 firm-year observations. Table 1 reports sample information. Of the 6,264 firm-years, 3,850 (61.46\%) observations represent firm-years when audited ICFR reports are disclosed. The rest of the sample (38.54\%) represents observations with no such disclosure. Of the 3,850 firm-years with audited ICFR disclosures, 1,708 (44.36\%) represent mandatory ICFR disclosures and 2,142 (55.64\%) represent voluntary ICFR disclosures. Industry distributions of the sample are also provided in Table 1 . As shown in the table, above $68 \%$ of the sampled firms are manufacturing firms. 
Table 1. Sample Information

Panel A: Disclosure of Audited ICFR Reports

\begin{tabular}{|c|c|c|c|}
\hline & & $\begin{array}{l}\text { Number } \\
\text { mandatory } \\
\text { disclosure }\end{array}$ & $\begin{array}{l}\text { Number of } \\
\text { voluntary disclosure }\end{array}$ \\
\hline Number of firm-years of disclosures & 3,850 & 1,708 & 2,142 \\
\hline Number of firm-years of non-disclosures & 2,414 & & \\
\hline Total & 6,264 & & \\
\hline
\end{tabular}

Panel B: Industry Distribution

\begin{tabular}{lll}
\hline Industry & Frequency & Percent \\
\hline Agriculture & 117 & $1.87 \%$ \\
Mining & 172 & $2.75 \%$ \\
Manufacturing & 4,270 & $68.17 \%$ \\
Utilities & 234 & $3.74 \%$ \\
Construction & 157 & $2.51 \%$ \\
Wholesale and Retail & 392 & $6.26 \%$ \\
Transportation, Storage, and Postal Services & 234 & $3.74 \%$ \\
Accommodation and Food Services & 35 & $0.56 \%$ \\
Information Technology & 333 & $5.32 \%$ \\
Leasing and Commercial Services & 71 & $1.13 \%$ \\
Research and Technological Services & 30 & $0.48 \%$ \\
Water Conservancy and Environment Administration & 55 & $0.88 \%$ \\
Residential Services & 10 & $0.16 \%$ \\
Culture, Sports, and Entertainment & 60 & $0.96 \%$ \\
Other & 94 & $1.50 \%$ \\
Total & 6,264 & $100 \%$ \\
\hline
\end{tabular}

\subsection{Variables and Model Specification}

Following prior literature, we use the absolute value of performance-adjusted discretionary accruals (ABSDA) as the proxy for earnings management. We estimate discretionary accruals based on the cross-sectional modified Jones Model (Dechow et al, 1995) with the addition of the current return on assets (ROA).

To examine whether attestation of ICFR discourages earnings management, we use "ICFR" as our primary independent variable. ICFR is a dummy variable which takes a value of "1" if a Chinese public firm discloses its ICFR audit report, and " 0 " otherwise. To address the research question, we use "Mandatory" as our primary independent variable in an additional analysis performed within firms that disclose audited ICFR reports. Mandatory is a dummy variable which takes value of " 1 " when a Chinese public firm is mandated to adopt China SOX, " 0 " otherwise.

We control firm characteristics that might be associated with discretionary accruals in the multiple regression model. For example, earnings management is negatively associated with audit quality. Chen et al. (2011) find that Chinese firms that are audited by the Top 8 accounting firms exhibit lower discretionary accruals compared to firms that are not audit by the Top 8 accounting firms. Prior research (e.g., Dechow \& Dichev, 2002; Hribar \& Nichols 2007; Xie et al., 2003) suggests that firm size is related to earnings management measures. Bartov et al. (2000) show that levered firms have more incentive to engage in earnings management activities. Compared to profitable firms, loss firms may exhibit different earnings management behavior (Xia \& Zhu, 2009). Ji et al. (2017) find that Chinese firms that have higher ROA show higher discretionary accruals. They suggest that firms showing better performance might be more likely to engage in earnings management. DeAngelo et al. (1994) and DeFond \& Jiambalvo (1994) find empirical evidence of abnormal accruals when firms face binding debt covenants. Prior research has indicated a 
relation between earnings management and the market to book value (MTB). For instance, Carver at al. (2011) and Gopalan and Jayaraman (2012) find a negative relationship between earnings management and MTB. Lo et al. (2017) show a positive relationship. About $42 \%$ of our sampled firms are state-owned enterprises (SOEs). Chinese SOEs and non-SOEs are subject to different agency problems and may exhibit different levels of earnings management. Chen at al. (2011) show that Chinese non-SOEs exhibit a lower level of earnings management compared to SOEs if audited by the Top 8 accounting firms.

To control the above factors, auditor reputation/quality (Bigauditor), firm size (Size), leverage (Debt), loss firms (Loss), return on assets (ROA), market to book value (MTB), and SOE are included as control variables. Industry effects are also controlled by including industry dummies in the regression models. Variable definitions are provided in Table 2.

Table 2. Variable Definitions

\begin{tabular}{ll}
\hline Variable & Definition \\
& \\
ABSDA & from the cross-sectional modified Jones Model (Dechow et al., 1995) \\
& $=1$ if the firm its audited ICFR report; \\
ICFR & $=1$ if the firm is mandated to disclose its audited internal control report, and 0 \\
Mandatory & otherwise; \\
& $=1$ if the firm's financial statement auditor is an international Big 4 or a Chinese \\
Bigauditor & national Big 10 accounting firm, and 0 otherwise; \\
Size & $=$ natural logarithm of total assets measured in RMB \\
Debt & $=$ total liabilities divided by total assets; \\
Loss & $=1$ if the firm reports a net loss at the end of fiscal year, and 0 otherwise; \\
ROA & $=$ total profit after tax scaled by total assets \\
MTB & $=$ market to book ratio, defined as the sum of the market value equity and the \\
SOE & book value of debt, scaled by total assets; \\
ENOI & $=1$ if the company is a state-owned enterprise, 0 otherwise. \\
\end{tabular}

In summary, the multiple regression models used to the hypothesis $(\mathbf{H})$ and answer the research question $(\mathbf{R Q})$ are specified as follows:

H:

$$
\begin{gathered}
A B S D A_{i t}=\alpha+\beta_{1} I_{C F R}+\beta_{2} \text { Bigauditor }_{i t}+\beta_{3} \text { Size }_{i t}+\beta_{4} \text { Loss }_{i t}+\beta_{5} \text { Debt }_{i t}+\beta_{6} \text { ROA }+\beta_{7} \text { MT }_{i t}+\beta_{8} \text { SOE }_{i t} \\
+ \text { Industry dummies }+\varepsilon_{i t}
\end{gathered}
$$

RQ:

$$
\begin{gathered}
A B S D A_{i t}=\alpha+\beta_{1} \text { Mandatory }_{i t}+\beta_{2} \text { Bigauditor }_{i t}+\beta_{3} \text { Size }_{i t}+\beta_{4} \text { Loss }_{i t}+\beta_{5} \text { Debt }_{i t}+\beta_{6} \text { ROA }+\beta_{7} \text { MTB }_{i t} \\
+\beta_{8} \text { SOE }_{i t}+\text { Industry dummies }+\varepsilon_{i t}
\end{gathered}
$$

\subsection{Descriptive Statistics}

Table 3 presents the basic descriptive statistics of ABSDA and control variables for the full sample. The mean and median of the dependent variable, ABSDA, are 0.0651 and 0.0448 , respectively. These values are about the same as the ABSDA in Ji et al. (2017) (Note 6). About $61 \%$ of all observations represent firm-years when audited ICFR reports are disclosed. The mean of Mandatory is 0.2727 , which indicates that about $27 \%$ of all observations represent firm-years for mandatory ICFR disclosures.

The means of dummy control variables, Bigauditor, Loss, and SOE are 0.6732, 0.0945, and 0.42, respectively. About $67 \%$ of all observations represent firm-years when the financial statement auditor is either an international Big 4 or a national Big 10 accounting firm. More than 9\% of observations represent firms-years with reported net loss. About $42 \%$ of the sample represent SOEs. 
The means of Size, debt, ROA, and MTB are 21.8147, 0.4376, 0.0607, and 1.7441, respectively.

Table 3. Descriptive Statistics

\begin{tabular}{llllll}
\hline & Mean & Median & Std. Deviation & Minimum & Maximum \\
\hline ICFR & 0.6146 & 1.0000 & 0.4867 & 0.0000 & 1.0000 \\
Mandatory & 0.2727 & 0.0000 & 0.4454 & 0.0000 & 1.0000 \\
ABSDA & 0.0651 & 0.0448 & 0.0665 & 0.0000 & 0.3217 \\
Bigauditor & 0.6732 & 1.0000 & 0.4691 & 0.0000 & 1.0000 \\
Size & 21.8147 & 21.7000 & 1.2769 & 18.0000 & 25.8000 \\
Loss & 0.0945 & 0.0000 & 0.2926 & 0.0000 & 1.0000 \\
Debt & 0.4376 & 0.4317 & 0.2379 & 0.0071 & 1.3000 \\
ROA & 0.0607 & 0.0563 & 0.0632 & -0.2207 & 0.2624 \\
MTB & 1.7441 & 1.3568 & 1.6235 & 0.2837 & 19.5000 \\
SOE & 0.4200 & 0.0000 & 0.4930 & 0.0000 & 1.0000 \\
\hline
\end{tabular}

All variables are defined in Table 2.

\subsection{Comparisons}

We make the following comparisons of ABSDA and control variables: (1) firms that disclose audited ICFR reports (i.e., ICFR=1) vs. firms that do not disclose ICFR reports (i.e., ICFR=0); (2) firms that are mandated to disclose audited ICFR reports (Mandatory=1) vs. firms that disclose audited ICFR reports voluntarily (ICFR=1 but Mandatory $=0$ ); (3) firms that disclose audited ICFR report voluntarily (ICFR=1 but Mandatory $=0$ ) vs. firms that do not disclose ICFR reports (ICFR $=0$ ). The results of these comparisons are presented in Panel A, Panel B, and Panel C of Table 4.

As shown in Panel A of Table 4, the mean of ABSDA (0.0602) for firms disclosing audited ICFR reports is significantly lower than the mean of ABSDA (0.0727) for firms not disclosing ICFR reports. This result is consistent with our expectation. According to the result, the firms that disclose audited ICFR reports are bigger, have lower level of debt, higher ROA, lower MTB, are more likely to have either an international Big 4 or national Big 10 accounting firm as their financial statement auditor, are less likely to report a loss, and are more likely to be a state-owned enterprise.

Panel B of Table 4 provides the comparison result within a group of Chinese firms that disclose audited ICFR reports. Within this group, some firms are mandated to disclose audited ICFR reports (mandatory firms) and others are not mandated to do so but choose to disclose audited ICFR reports voluntarily (voluntary firms). The result shows that mandatory firms exhibit significantly lower ABSDA (mean ABSDA $=0.0578$ ) than voluntary firms (mean $\mathrm{ABSDA}=0.0622$ ). Consistent with what the China SOX adoption timelines suggest, mandatory firms (mean size $=$ 22.6782 ) are significantly bigger than the voluntary firms (mean size $=21.4979$ ). Interestingly, mandatory firms have higher debt, lower ROA, higher MTB, and are more likely to experience a loss than voluntary firms.

Panel $\mathrm{C}$ of Table 4 provides the comparison result within a group of Chinese firms that have not yet been mandated to adopt China SOX. Within this group, some firms choose to disclose audited ICFR reports (voluntary firms) in their annual reports, while others choose not to disclose ICFR reports (non-disclosing firms). The result shows that voluntary firms exhibit significantly lower ABSDA (mean ABSDA=0.0622) than non-disclosing firms (mean ABSDA $=0.0727$ ). The voluntary firms and non-disclosing firms are about the same size. On average, voluntary firms have lower debt, higher ROA, lower MTB, are less likely to experience a loss, and are more likely to have either an international Big 4 or national Big 10 accounting firm as their financial statement auditor. 
Table 4. Comparisons

\begin{tabular}{|c|c|c|c|c|}
\hline \multirow[t]{2}{*}{ Panel A: } & \multirow{2}{*}{$\begin{array}{l}\text { Firms disclosing audited ICFR } \\
\text { reports } \\
\mathrm{N}=3,850\end{array}$} & \multirow{2}{*}{$\begin{array}{l}\text { Firms not disclosing } \\
\text { audited ICFR reports } \\
\mathrm{N}=2,414\end{array}$} & \multirow[b]{2}{*}{ t-statisics } & \multirow[b]{2}{*}{ P-value } \\
\hline & & & & \\
\hline ABSDA & 0.0602 & 0.0727 & -7.247 & 0.000 \\
\hline Size & 22.0215 & 21.4848 & 16.541 & 0.000 \\
\hline Debt & 0.4326 & 0.4455 & -2.094 & 0.036 \\
\hline ROA & 0.0621 & 0.0585 & 2.220 & 0.026 \\
\hline MTB & 1.5950 & 1.9820 & -9.242 & 0.000 \\
\hline$\underline{\text { Dummies }}$ & & & chi-square & P-value \\
\hline Loss & 0.0839 & 0.1100 & 13.147 & 0.000 \\
\hline Bigauditor & 0.7100 & 0.6200 & 48.905 & 0.000 \\
\hline SOE & 0.5100 & 0.2600 & 409.303 & 0.000 \\
\hline Panel B & Mandatory disclosing firms & $\begin{array}{l}\text { Voluntary disclosing } \\
\text { firms }\end{array}$ & & \\
\hline & $\mathrm{N}=1,708$ & $\mathrm{~N}=2,142$ & t-statisics & P-value \\
\hline ABSDA & 0.0578 & 0.0622 & -2.196 & 0.028 \\
\hline Size & 22.6782 & 21.4979 & 30.734 & 0.000 \\
\hline Debt & 0.5369 & 0.3494 & 28.063 & 0.000 \\
\hline ROA & 0.0529 & 0.0695 & -8.849 & 0.000 \\
\hline MTB & 1.5010 & 1.6700 & -4.786 & 0.000 \\
\hline Dummies: & & & chi-square & P-value \\
\hline Loss & 0.1247 & 0.0514 & 66.527 & 0.000 \\
\hline Bigauditor & 0.6821 & 0.4658 & 13.288 & 0.000 \\
\hline SOE & 0.8940 & 0.2124 & 1767.499 & 0.000 \\
\hline Panel C: & $\begin{array}{l}\text { Voluntary disclosing firms } \\
\mathrm{N}=2,142\end{array}$ & $\begin{array}{l}\text { Firms not disclosing } \\
\text { audited ICFR reports } \\
\mathrm{N}=2,414\end{array}$ & t-statisics & P-value \\
\hline ABSDA & 0.0622 & 0.0727 & -5.135 & 0.000 \\
\hline Size & 21.4979 & 21.4848 & 0.411 & 0.681 \\
\hline Debt & 0.3494 & 0.4455 & -13.817 & 0.000 \\
\hline ROA & 0.0695 & 0.0585 & 5.801 & 0.000 \\
\hline МTB & 1.6700 & 1.9820 & -5.974 & 0.000 \\
\hline Dummies: & & & chi-square & P-value \\
\hline Loss & 0.0500 & 0.1100 & 53.714 & 0.000 \\
\hline Bigauditor & 0.6800 & 0.6200 & 18.714 & 0.000 \\
\hline SOE & 0.2124 & 0.2600 & 11.976 & 0.000 \\
\hline
\end{tabular}

All variables are defined in Table 2.

Correlations among ABSDA, ICFR, Mandatory, and control variables are provided in Table 5. Pearson correlations are reported on the upper diagonal and Spearman rank order correlations are reported on the lower diagonal. As expected, the dependent variable ABSDA is negatively associated with ICFR. The correlation between ABSDA and Mandatory is also negative and significant. 
Table 5. Correlations

\begin{tabular}{|c|c|c|c|c|c|c|c|c|c|c|}
\hline & ABSDA & ICFR & Mandatory & Bigauditor & Size & Loss & Debt & ROA & MTB & SOE \\
\hline ABSDA & 1 & $-.091^{* *}$ & $-.066^{* *}$ & $-.042^{* *}$ & $-.121^{* *}$ & $.124^{* *}$ & $.154^{* * *}$ & -0.004 & $.222^{* * *}$ & $-.041^{\text {** }}$ \\
\hline ICFR & $-.072^{* *}$ & 1 & $.485^{* *}$ & $.088^{* *}$ & $.205^{* *}$ & $-.046^{* *}$ & $-.026^{*}$ & $.028^{*}$ & $-.116^{* *}$ & $.256^{* *}$ \\
\hline Mandatory & $-.050^{* * *}$ & $.485^{* *}$ & 1 & $.082^{* *}$ & $.414^{* * *}$ & $.063^{* * *}$ & $.256^{* * *}$ & $-.076^{* *}$ & $-.092^{* *}$ & $.595^{* *}$ \\
\hline Bigauditor & $-.033^{* *}$ & $.088^{* * *}$ & $.082^{* *}$ & 1 & $.121^{* *}$ & -0.005 & -0.007 & 0.014 & $-.032^{*}$ & $.069^{* *}$ \\
\hline Size & $-.069^{* * *}$ & $.177^{* * *}$ & $.398^{* * *}$ & $.094^{* *}$ & 1 & $-.073^{* *}$ & $.372^{* * *}$ & $.088^{* * *}$ & $-.403^{* *}$ & $.408^{* *}$ \\
\hline Loss & $.117^{* *}$ & $-.046^{* *}$ & $.063^{* *}$ & -0.005 & $-.065^{* *}$ & 1 & $.270^{* *}$ & $-.578^{* *}$ & $.109^{* * *}$ & $.050^{* *}$ \\
\hline Debt & $.098^{* *}$ & -0.006 & $.278^{* *}$ & -0.004 & $.474^{* *}$ & $.231^{* *}$ & 1 & $-.276^{* *}$ & $.050^{* * *}$ & $.307^{* *}$ \\
\hline ROA & 0.017 & $.030^{*}$ & $-.096^{* *}$ & 0.003 & $.079^{* *}$ & $-.492^{* *}$ & $-.244^{* *}$ & 1 & $.053^{* *}$ & $-.058^{* * *}$ \\
\hline MTB & $.114^{* * *}$ & $-.101^{* *}$ & $-.157^{* *}$ & $-.056^{* *}$ & $-.479^{* * *}$ & $.047^{* *}$ & $-.186^{* *}$ & $.178^{* * *}$ & 1 & $-.102^{* * *}$ \\
\hline SOE & -0.024 & $.256^{* * *}$ & $.595^{* *}$ & $.069^{* *}$ & $.404^{* *}$ & $.050^{* *}$ & $.337^{* * *}$ & $-.089^{* *}$ & $-.118^{* *}$ & 1 \\
\hline
\end{tabular}

All variables are defined in Table 2. Pearson (Spearman) correlations are presented in the upper (lower) diagonal. Significant correlations are bolded. $* *$ and $*$ reflect significance at 0.01 and 0.05 level, respectively.

\section{Regression Results and Discussions}

\subsection{Attestation of ICFR and Discretionary Accruals}

To examine whether attestation of ICFR discourages earnings management and therefore improve financial reporting quality, we regress the dependent variable ABSDA on the primary independent variable ICFR and control variables that might impact discretionary accruals. The regression result is reported in Table 6. All independent variables except Bigauditor are statistically significant and the adjusted $R^{2}$ is $9.6 \%$. According to this result, bigger firms show lower absolute discretionary accruals; while loss firms, more levered firms, and undervalued firms show a higher level of absolute discretionary accruals. After controlling these factors, we find a significantly negative association between ICFR and ABSDA. This result indicates that Chinese public firms that disclose audited ICFR reports exhibit lower absolute discretionary accruals than firm that do not disclose ICFR reports. Such a result supports the hypothesis.

Table 6. The Impact of Attestation of ICFR on Absolute Discretionary Accruals

\section{Dependent Variable: ABSDA}

\begin{tabular}{|c|c|c|c|c|}
\hline Independent variables & Expected sign & Coefficient & t-statistics & P-value \\
\hline ICFR & - & -0.035 & -2.621 & 0.009 \\
\hline Bigauditor & - & -0.013 & -1.420 & 0.156 \\
\hline Size & $?$ & -0.204 & -7.980 & 0.000 \\
\hline Loss & + & 0.140 & 7.846 & 0.000 \\
\hline Debt & + & 0.245 & 13.644 & 0.000 \\
\hline ROA & + & 0.159 & 7.793 & 0.000 \\
\hline MTB & $?$ & -0.023 & -2.611 & 0.009 \\
\hline SOE & + & -0.030 & -2.128 & 0.033 \\
\hline Industries & Yes & & & \\
\hline Number of observations & 6,264 & & & \\
\hline Adjusted R-square & $9.6 \%$ & & & \\
\hline F-statistics & 75.239 & & & \\
\hline
\end{tabular}

All variables are defined in Table 2. Significant coefficients are bolded

\subsection{Mandatory Disclosures vs. Voluntary Disclosures}

To answer the research question, we run a multiple regression analysis using a sub-sample of Chinese firms that disclose audited ICFR reports (i.e., non-disclosing firms are removed from the sample). Within this sub-sample, 1,708 firm-year observations represent mandatory disclosures and 2,142 represent voluntary disclosures. We regress 
the dependent variable ASBDA on the primary independent variable Mandatory and control variables. As stated earlier, there are two competing theories and mandatory firms may or may not exhibit more effective ICFR and therefore lower earnings management compared to voluntary firms. The regression result is provided in Table 7. The coefficient on the primary independent variable, Mandatory, is negative and significant. On average, mandatory firms exhibit lower absolute discretionary accruals than voluntary firms. The coefficients on all control variables but MTB are similar to the result using the full sample.

Table 7. Mandatory vs. Voluntary Attestation of ICFR

\section{Dependent Variable: ABSDA}

\begin{tabular}{|c|c|c|c|c|}
\hline Independent variables & Expected sign & Coefficient & t-statistics & P-value \\
\hline Mandatory & $?$ & -0.057 & -2.523 & 0.012 \\
\hline Bigauditor & - & -0.026 & -1.600 & 0.110 \\
\hline Size & $?$ & -0.091 & -4.084 & 0.000 \\
\hline Loss & + & $\mathbf{0 . 0 8 8}$ & 4.536 & 0.000 \\
\hline Debt & + & 0.141 & 6.827 & 0.000 \\
\hline ROA & + & 0.072 & 3.486 & 0.000 \\
\hline MTB & $?$ & 0.092 & 5.170 & 0.000 \\
\hline SOE & + & -0.003 & -0.133 & 0.895 \\
\hline Industries & Yes & & & \\
\hline Number of observations & 3,850 & & & \\
\hline Adjusted R-square & $3.9 \%$ & & & \\
\hline F-statistics & 18.391 & & & \\
\hline
\end{tabular}

All variables are defined in Table 2. Significant coefficients are bolded.

Note that this result is inconsistent with the result in Hermanson (2000). Hermanson (2000) analyzes the demand for reporting on internal control by surveying financial statement users. According to her survey, information users agreed that both voluntary and mandatory report on internal controls would improve controls. However, the users held neutral on "mandatory internal report would do little to improve financial reporting quality". These users recommend that firms should be encouraged but not required to provide report on internal control. Our study provides empirical evidence that mandatory requirement on ICFR report and attestation may add more value to credibility of financial reporting.

\subsection{Voluntary Disclosures vs. Non-disclosures}

Because firms that are mandated to adopt China SOX might be fundamentally different from other firms, we removed mandatory firms from the sample and compare firms that voluntarily disclose audited ICFR reports with firms that do not disclose ICFR reports. The regression result is provided in Table 8 . The coefficient on the primary independent variable, ICFR, is negative and significant. On average, firms that disclose audited ICFR reports exhibit lower absolute discretionary accruals than firms that do not. Among firms that are not mandated to adopt China SOX, firms that choose to have their ICFR audited show lower earnings management. This supports the hypothesis. Coefficients on other variables are similar to the result using the full sample. 
Table 8. Voluntary Attestation vs. Non-compliance Accruals

\section{Dependent Variable: ABSDA}

\begin{tabular}{lllll}
\hline $\begin{array}{l}\text { Independent } \\
\text { variables }\end{array}$ & $\begin{array}{l}\text { Expected } \\
\text { sign }\end{array}$ & Coefficient & t-statistics & P-value \\
\hline ICFR & - & $\mathbf{- 0 . 0 2 9}$ & $\mathbf{- 1 . 9 4 1}$ & $\mathbf{0 . 0 5 2}$ \\
Bigauditor & - & -0.017 & -1.182 & 0.237 \\
Size & $?$ & $\mathbf{- 0 . 1 1 7}$ & $\mathbf{- 6 . 4 2 2}$ & $\mathbf{0 . 0 0 0}$ \\
Loss & + & $\mathbf{0 . 1 3 7}$ & $\mathbf{7 . 8 1 4}$ & $\mathbf{0 . 0 0 0}$ \\
Debt & + & $\mathbf{0 . 2 2 7}$ & $\mathbf{1 3 . 3 2 8}$ & $\mathbf{0 . 0 0 0}$ \\
ROA & + & $\mathbf{0 . 1 4 7}$ & $\mathbf{8 . 2 0 7}$ & $\mathbf{0 . 0 0 0}$ \\
MTB & $?$ & $\mathbf{0 . 1 2 3}$ & $\mathbf{7 . 4 0 4}$ & $\mathbf{0 . 0 0 0}$ \\
SOE & + & -0.014 & -0.977 & 0.329 \\
Industries & Yes & & & \\
Number of observations & 4,556 & & \\
Adjusted R-square & & $11.1 \%$ & & \\
F-statistics & & 64.279 & & \\
\hline
\end{tabular}

All variables are defined in Table 2. Significant coefficients are bolded.

\subsection{Robustness Tests}

It is well known that discretionary accruals have limitations in measuring earnings management. Following previous studies that examine earnings management in China (e.g., Cang et al., 2014; Chen and Yuan 2004), we use "excess non-operating income" (ENOI) as an alternative measure for earnings management. To test the hypothesis, we run the multiple regression with the dependent variable ENOI. The result is presented in Table 9. This result is similar to the result presented in Table 6, when ABSDA is used as the dependent variable.

Table 9. Additional Analysis: the Impact of Attestation of ICFR on the Excess Non-operating Income

\section{Dependent Variable: ENOI}

\begin{tabular}{lllll}
\hline $\begin{array}{l}\text { Independent } \\
\text { variables }\end{array}$ & $\begin{array}{l}\text { Expected } \\
\text { sign }\end{array}$ & Coefficient & t-statistics & P-value \\
\hline ICFR & - & $\mathbf{- 0 . 0 2 6}$ & -2.131 & 0.033 \\
Bigauditor & - & -0.002 & -0.146 & 0.884 \\
Size & $?$ & $\mathbf{- 0 . 1 8 8}$ & $\mathbf{- 1 2 . 1 7 0}$ & $\mathbf{0 . 0 0 0}$ \\
Loss & + & $\mathbf{0 . 0 7 3}$ & $\mathbf{5 . 0 9 9}$ & $\mathbf{0 . 0 0 0}$ \\
Debt & + & $\mathbf{0 . 4 1 0}$ & $\mathbf{2 9 . 1 6 0}$ & $\mathbf{0 . 0 0 0}$ \\
ROA & + & $\mathbf{0 . 1 4 7}$ & $\mathbf{9 . 9 8 8}$ & $\mathbf{0 . 0 0 0}$ \\
MTB & $?$ & $\mathbf{0 . 0 7 3}$ & $\mathbf{5 . 4 9 2}$ & $\mathbf{0 . 0 0 0}$ \\
SOE & + & $\mathbf{0 . 0 9 8}$ & $\mathbf{7 . 4 2 1}$ & $\mathbf{0 . 0 0 0}$ \\
Industries & Yes & & & \\
Number of observations & 6,264 & & \\
Adjusted R-square & & $18 \%$ & & \\
F-statistics & & 153.393 & & \\
\hline
\end{tabular}

All variables are defined in Table 2. Significant coefficients are bolded

Although our results seem to suggest that Chinese firms that disclose audited ICFR reports exhibit lower absolute discretionary accruals, it is possible that these firms already had more effective ICFR, higher financial reporting quality, and therefore lower discretionary accruals before they adopt China SOX. To control for the possible 
selection bias, we perform a paired t-test within a list of firms $(n=879)$ that started to disclose the audited ICFR either in fiscal year 2012 or 2013. For these firms, we can perform a pre post comparison within our sample period 2011-2013. Specifically, we compare the absolute discretionary accruals (i.e., ABSDA) in the year before ICFR disclosure and in the first year of ICFR disclosure. The average ABSDA significantly reduced to 0.0628 in the first year of SOX adoption from 0.0743 in the prior year $(t-s t a t=3.204)$. This result indicates that firms experience decreased earnings management in the year when audited ICFR reports are disclosed.

\section{Summary and Limitations}

China SOX aims to improve financial reporting and emphasizes effective ICFR. Since 2010, adopting firms are required to report on and attest to the effectiveness of their ICFR. Effective ICFR should provide reasonable assurance that the company's financial statements are reliable and prepared in accordance with the applicable accounting standards. The primary goal of this study is to examine whether attestation of ICFR discourages earnings management.

We analyze a sample of Chinese public firms for the period of 2011 to 2013. Consistent with our expectation, firms that disclose audited ICFR reports exhibit lower absolute discretionary accruals than firms that do not. Such a result is robust to an alternative earnings management measure. Additionally, we find that firms that are mandated to disclose audited ICFR reports exhibit lower earnings management than firms that voluntarily disclose audited ICFR reports. To control for the possible selection bias, we performed a pre-post comparison for a list of firms that adopted China SOX in year 2012 or 2013. We find that the absolute discretionary accruals in the first year of audited ICFR disclosure is significantly lower than that in year 2011.

Overall, our results suggest that attestation of ICFR discourages earnings management. The findings of this study have implications to regulators and researchers. Specifically, this study seems to support the notion that China SOX compliance improves financial reporting quality and therefore provides positive feedback to Chinese regulators. It adds more evidence in supporting the positive relationship between audit assurance of ICFR and financial reporting quality. It also provide support on the mandatory requirement on attestation of ICFR report.

This study has obvious limitations. Some studies (i.e., Dowdell et al., 2014; Kinney \& Shepardson, 2011) have shown that management report on ICFR alone (without attestation) would improve financial reporting quality. Although our results show that Chinese firms that disclose audited ICFR reports exhibit lower earnings management, it is unclear whether such a result is driven by management report on ICFR or attestation of ICFR or both. More specifically, this study has not addressed this question: Does management report alone improve financial reporting without attestation? Another issue is related to the compliance cost. Is it cost effective to require all Chinese public firms to adopt China SOX? Future studies should address these two important questions.

\section{References}

Altamuro, J. \& Beatty, A. (2010). How does internal control regulation affect financial reporting? Journal of Accounting and Economics, 49(1-2), 58-74. https://doi.org/10.1016/j.jacceco.2009.07.002

Ashbaugh-Skaife, H., Collins, D., Kinney, W., \& LaFond, R. (2008). The effect of SOX internal control deficiencies and their remediation on accrual quality. The Accounting Review, 83(1), 217-250. https://doi.org/10.2308/accr.2008.83.1.217

Bamber, E. M., Bamber, L. S., \& M. P. Schoderbek. (1993). Audit structure and other determinants of audit report lag: An empirical analysis. Auditing: A Journal of Practice and Theory, 12(1), 1-23.

Bartov, E., Gul, F., \&Tsui, J. (2000). 'Discretionary-accruals models and audit qualifications. Journal of Accounting and Economics, 30(3), 421-452. https://doi.org/10.1016/S0165-4101(01)00015-5

Bell, T.B. \& Carcello, J.V. (2000) A Decision aid for assessing the likelihood of fraudulent financial reporting. Auditing: A Journal of Practice and Theory, 19(1), 169-184. https://doi.org/10.2308/aud.2000.19.1.169

Brown, N.C., Pott, P., \& Wömpener, A. (2014). The effect of internal control and risk management regulation on earnings quality: evidence from Germany. Journal of Accounting and Public Policy, 33(1), 1-31. https://doi.org/10.1016/j.jaccpubpol.2013.10.003

Cang, Y, Y. Chu \& T.W. Lin. (2014). An exploratory study of earnings management detectability, analyst coverage and the impact of IFRS adoption: evidence from China. Journal of Accounting and Public Policy, 33(4), 356-371. https://doi.org/10.1016/j.jaccpubpol.2014.04.003 
Carver, B.T., Hollingsworth, C.W., \& Stanley, J.D. (2011). Recent auditor downgrade activity and changes in clients' discretionary accruals. Auditing: A Journal of Practice and Theory, 30(3), 33-58. https://doi.org/10.2308/ajpt-10053

Cendrowski, S. (2015, July 22). China's global 500 companies are bigger than ever-and mostly state-owned. Retrieved July $30, \quad 2018, \quad$ from http://fortune. com/2015/07/22/china-global-500-government-owned.

Chan, K., Farrell, B., \& Lee, P., (2009). Earnings management of firms reporting material internal control weaknesses under Section 404 of the Sarbanes-Oxley Act. Auditing: A Journal of Practice and Theory, 27(2), 161-179. https://doi.org/10.2308/aud.2008.27.2.161

Chen, H., Chen, J.Z., Lobo, G.J., \& Wang Y., (2011). The effects of earnings management and cost of capital: evidence from China. Contemporary Accounting Research, 28(3), 892-925. https://doi.org/10.1111/j.1911-3846.2011.01088.x

Chen, K. \& H. Yuan. (2004). Earnings management and capital resource allocation: evidence from china's accounting-based regulation of rights issues. The Accounting Review, 79(3), 645-665. https://doi.org/10.2308/accr.2004.79.3.645

Committee of Sponsoring Organizations of the Treadway Commission (COSO), (1992). Internal Control Integrated Framework. AICPA: New York, NY.

DeAngelo, H., DeAngelo, L, \& Skinner, D. (1994). Accounting choice in troubled companies. Journal Of Accounting And Economics, 17(1-2), 113-143. https://doi.org/10.1016/0165-4101(94)90007-8

Dechow, P., Sloan, R., \& Sweeney, A. (1995). Detecting earnings management. The Accounting Review, 70(2), 193-225.

Dechow, P., Dichev, I. (2002). The quality of accruals and earnings. The Accounting Review, 77(supplement), 35-59. https://doi.org/10.2308/accr.2002.77.s-1.35

DeFond, M. \& Jiambalvo, J. (1994). Debt covenant violation and manipulation of accruals. Journal of Accounting and Economics, 17(1-2), 145-176. https://doi.org/10.1016/0165-4101(94)90008-6

Dowdell Jr., T.D., Herda, D.N., \& Notbohm, M.A. (2014). Do management reports on internal control over financial reporting improve financial reporting? Research in Accounting Regulation, 26(1), 104-109. https://doi.org/10.1016/j.racreg.2014.02.011

Doyle, J., Ge, W., \& McVay, S. (2007). Accruals quality and internal control over financial reporting. The Accounting Review, 82(5), 1141-1170. https://doi.org/10.2308/accr.2007.82.5.1141

Feng, M, Li, C., McVay, S.E., \& Skaife, H. (2015). Does ineffective internal control over financial reporting affect a firm's operations? Evidence from firms' inventory management. The Accounting Review, 90(2), 529-557. https://doi.org/10.2308/accr-50909

Foster, B.P. \& Shastr, T. (2013). Material internal control weaknesses and earnings management in the post-sox environment. Journal of Applied Business Research, 29(1), 183-194. https://doi.org/10.19030/jabr.v29i1.7566

Gopalan, R. \& Jayaraman, S. (2012). Private control benefits and earnings management: evidence from insider controlled firms, Journal of Accounting Research, 50(1), 117-157. https://doi.org/10.1111/j.1475-679X.2011.00431.x

He, L. \& Thorton, D.B. (2013). The impact of disclosures of internal control weaknesses and remediations on investors' perceptions of earnings quality. Accounting Perspectives, 12(2), 101-140. https://doi.org/10.1111/1911-3838.12011

Hermanson, H.M., (2000). An analysis on the demand for reporting on internal control. Accounting Horizons, 14(3), 325-341. https://doi.org/10.2308/acch.2000.14.3.325

Hribar, P. \& Nichols, C. (2007). The use of unsigned earnings quality measures in tests of earnings management. Journal of Accounting Research, 45(5), 1017-53. https://doi.org/10.1111/j.1475-679X.2007.00259.x

Ji, X., Lu, W., \& Qu, W. (2015). Determinants and economic consequences of voluntary disclosure of internal control weaknesses in China. Journal of Contemporary Accounting \& Economics, 11(1), 1-17. https://doi.org/10.1016/j.jcae.2014.12.001 
. 2016 Internal control weaknesses and accounting conservatism in China. Managerial Auditing Journal, 31(6-7), 688-726.

2017 Internal control weaknesses and accounting conservatism in China. International Journal of Accounting, 52(1), 27-44.

Jiambalvo, J. (1996). Discussion of "Causes and consequences of earnings manipulation: an analysis of firms subject to enforcement actions by the SEC". Contemporary Accounting Research, 13(1), 37-47. https://doi.org/10.1111/j.1911-3846.1996.tb00490.x

Kinney, W. \& McDaniel, L. (1989). Characteristics of firms correcting previously reported quarterly earnings. Journal of Accounting and Economics, 11(1), 71-93. https://doi.org/10.1016/0165-4101(89)90014-1

Kinney, W. R., \& Shepardson, M. L. (2011). Do control effectiveness disclosures require SOX 404(b) internal control audits? A natural experiment with small U.S. public companies. Journal of Accounting Research, 49(2), 413-448. https://doi.org/10.1111/j.1475-679X.2011.00400.x

Krishnan, G.V., \& Yu, W. (2012). Do small firms benefit from auditor attestation of internal control effectiveness? Auditing: A Journal of Practice \& Theory, 34(1), 115-137. https://doi.org/10.2308/ajpt-50238

Lo, H., Ramos, F., \& Rogo, R. (2017). Earnings management and annual report readability. Journal of Accounting and Economics, 63(1), 1-25. https://doi.org/10.1016/j.jacceco.2016.09.002

Lu, H., Richardson, G., \& Salterio, S. (2011). Direct and indirect effects of internal control weaknesses on accrual quality: evidence from a unique Canadian regulatory setting. Contemporary Accounting Research, 28(2), 675-707. https://doi.org/10.1111/j.1911-3846.2010.01058.x

Nagy, A.L. (2010.) Section 404 compliance and financial reporting quality. Accounting Horizons, 24(3), $441-454$. https://doi.org/10.2308/acch.2010.24.3.441

Singer, Z. \& You, H. (2011). The effect of Section 404 of the Sarbanes-Oxley Act on earnings quality. Journal of Accounting, Auditing, and Finance, 26?(3), 556-589. https://doi.org/10.1177/0148558X11401554

Xia, D. \& Zhu, D. (2009). Corporate governance and accounting conservatism in china. China Journal of Accounting Research, 2(2), 81-108. https://doi.org/10.1016/S1755-3091(13)60015-5

Xie, B., Davidson III, W. N. \& DaDalt, P. J. (2003). Earnings management and corporate governance: the role of the board and the audit committee. Journal of Corporate Finance, 9(3), 295-316. https://doi.org/10.1016/S0929-1199(02)00006-8 


\section{Appendix A: Adoption Timelines of the Basic Standard}

\section{Firm Characteristics}

Concurrently listed in domestic and oversea markets

Central and local SOEs listed on the main board

Non-SOEs listed on the main board whose total market value is above $¥ 5$ billion as of December 31, 2011 and whose average net profit from 2009 to 2011 is above $¥ 30$ million

Other firms that listed on the main board

Firms listed on the small-medium size board

Firms listed on the GEM

$\begin{array}{ll}\begin{array}{l}\text { Mandatory } \\ \text { Adoption Year }\end{array} & \text { Basic Requirement } \\ 2011 & \\ 2012 & \begin{array}{l}\text { Adopting companies should } \\ \text { disclose a self-assessment } \\ \text { report by the board of } \\ \text { directors on the effectiveness } \\ \text { of their internal control and an } \\ \text { external auditor's report on } \\ \text { the effectiveness of internal } \\ \text { control over financial } \\ \text { reporting }\end{array} \\ \end{array}$

TBD

\section{Notes}

Note 1. These three internal control regulatory documents include: (1) the Basic Standard for Enterprise Internal Control (issued in May, 2008); (2) the Supporting Guidelines for Internal Control of Enterprises (issued in April, 2010); and (3) the Notice on the Adoption of the Basic Standard of Enterprise Internal Control by Companies Listed on the Main Board under Different Categories and Groups as of 2012 (issued in August, 2012)

Note 2. Brown et al. (2014) provide a comparison of internal control and risk management in Germany, US, and other international jurisdictions including China.

Note 3. The five elements of the Basic Standard (2008) include "internal control environment", "risk assessment", "control activities", "information and communication", and "internal auditing".

Note 4. Mandatory adoptions of China SOX started in fiscal year 2011. ICFR audit reports before 2011 were all voluntary. Moreover, the timelines of mandatory adoptions are different for different groups of companies. That means during 2011-2013, mandatory and voluntary adoptions coexisted. See Appendix A for adoption timelines.

Note 5. The five Chinese government departments refer to the Chinese Ministry of Finance, the China Security Regulatory Commission (CSRC), the National Audit Office, the China Banking Regulatory Commission (CBRC), and the China Insurance Regulatory Commission (CIRC).

Note 6. Ji et al. (2017) analyzed a sample of Chinese firms that voluntarily disclosed ICWs in either 2010 or 2011. The mean and median ABSDA are 0.06 and 0.42 , respectively. 